\title{
The Oligocene/Miocene boundary in the ON-Mol-1 and Weelde boreholes along the southern margin of the North Sea Basin, Belgium
}

\author{
DIRK K. MUNSTERMAN ${ }^{1 *} \&$ JEF DECKERS ${ }^{2}$
}

${ }^{I}$ TNO, Toegepast Natuurwetenschappelijk Onderzoek (Netherlands Organization for Applied Scientific Research), Geological Survey of the Netherlands, Princetonlaan 6, 3584 CB Utrecht, The Netherlands; dirk.munsterman@tno.nl. ${ }^{2}$ VITO, Flemish Institute for Technological Research, Boeretang 200, Mol, Belgium; jef.deckers@vito.be. * corresponding author.

ABSTRACT. Based on palynologic interpretations, the Oligocene/Miocene boundary was identified in the cored samples of the ON-Mol-1 and Weelde boreholes in the southern North Sea Basin. In both boreholes, the presumed location of the Oligocene/Miocene boundary is marked by a thin gravel bed, which testifies of a hiatus, within a continuation of shelly, dark green to black fine glauconitic sands. In the Weelde borehole, the hiatus is relatively short as the dinocysts under- and overlying the gravel bed suggest a late(st) Chattian and early Aquitanian age. This study thereby for the first time indicates the presence of Aquitanian strata in the area.

In the ON-Mol-1 borehole, located south of the Weelde borehole, the hiatus is longer as dinocysts under- and overlying the gravel bed suggest an early Chattian and late Aquitanian age. The wider ranges of the hiatus might be the result of the combination of erosion/non-deposition of late Chattian strata and the gradual transgression of the southern North Sea Basin from north to south after the Oligocene/Miocene sea-level fall. The sampled interval around the Oligocene/Miocene boundary contains a lot of reworked Paleogene (including irregular upper Oligocene species occurrences) and Mesozoic taxa, which explains why the Miocene strata in the ON-Mol-1 and Weelde boreholes were dated as Chattian by previous studies.

KEYWORDS: Palynology, dinoflagellate cysts, age assessment, facies, reworking, gravel beds, Campine Block, Savian phase.

\section{Introduction}

During the late Oligocene and Neogene, glauconitic sands were deposited in shallow marine conditions across the southern North Sea Basin (Fig. 1). The deposition of these glauconitic sands was not continuous, but interrupted by several hiatuses. One of the most important and widespread hiatuses in the southern North Sea Basin coincides with the Oligocene/Miocene boundary, in the Netherlands often referred to as Savian phase (in Wong et al., 2001; Verbeek et al., 2002; Munsterman \& Brinkhuis, 2004). In the northern Campine Block, a structural entity along the southern margin of the North Sea Basin, this hiatus coincides with the boundary between the Voort and Berchem Formations (Figs 2 and 3). Here, age information on the late Oligocene Voort Formation was mainly based on biostratigraphic and radiometric studies on cored sections of the ON-Mol-1 (DOV
ON-Mol-1) and Weelde boreholes (DOV kb8d8e-B161; cf. Van Simaeys, 2004; Van Simaeys et al. 2004; 2005; De Man \& Van Simaeys, 2004; De Man et al., 2010). The age information on the early to middle Miocene Berchem Formation was then again based on biostratigraphic studies in its outcropping areas near and within the city of Antwerp and in several boreholes across the northern Campine Block (Louwye, 2005 and references therein), not including the ON-Mol-1 and Weelde boreholes. As the Voort and Berchem Formations were studied separately, the boundary between them or the Oligocene/Miocene hiatus was not yet biostratigraphically analysed in boreholes in the northern Campine Block, which resulted in limited knowledge on its exact timing and influence upon palaeoenvironmental conditions.

In order to study the Oligocene/Miocene boundary along the southern margin of the North Sea Basin, we resampled the cored

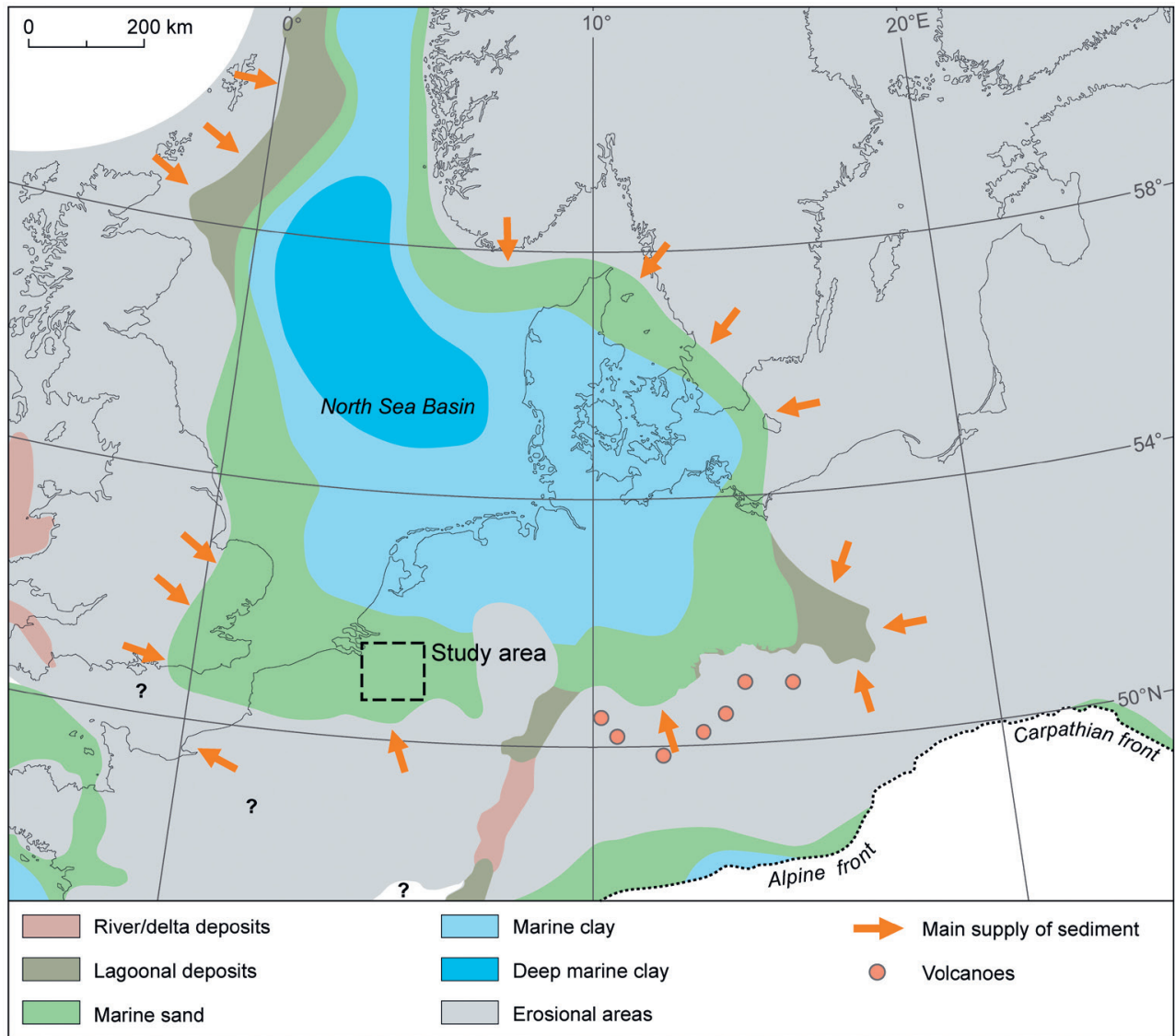

Figure 1. The late Oligocene (middle Chattian) palaeogeography of the North Sea Basin and surrounding areas, modified from Gibbard \& Lewin (2016). The study area of Figure 2 is indicated. 


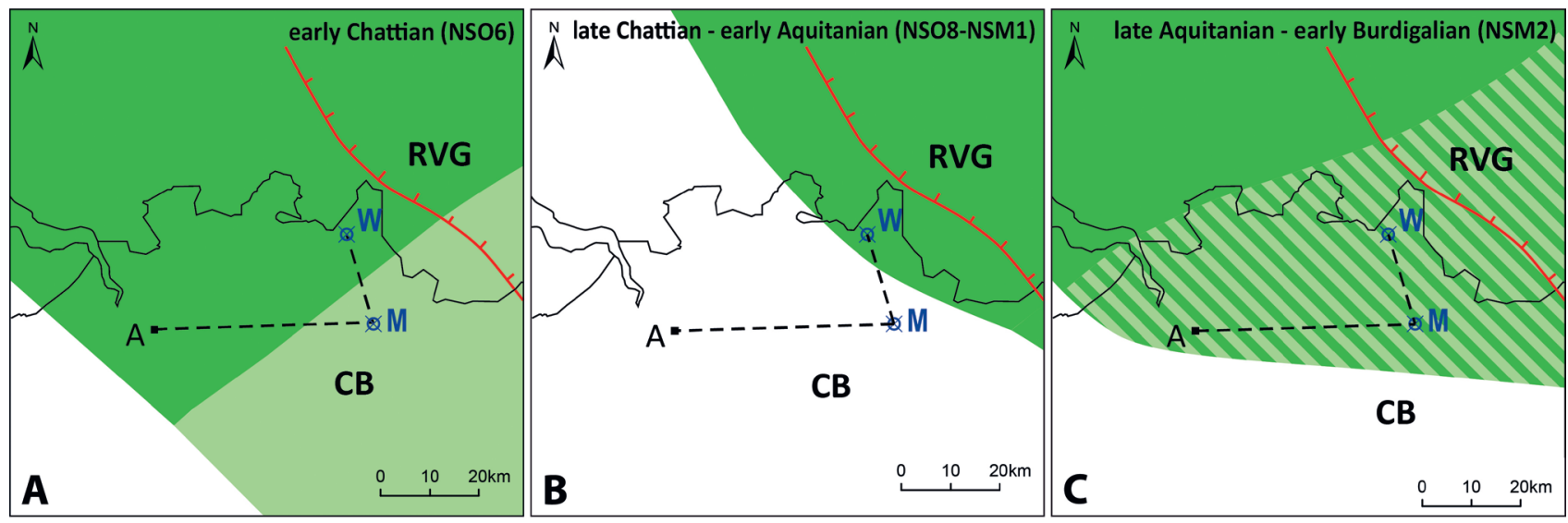

LEGEND Shallow - open marine Restricted marine a city w well - Profile Fig. 6 工 Roer Valley Graben border fault system

Figure 2. The study area with the location of the ON-Mol-1 (DOV ON-Mol-1) and Weelde (DOV kb8d8e-B161) boreholes, the schematic cross section of Figure 6 and the palaeogeographic maps during the Chattian, early Aquitanian and late Aquitanian to early Burdigalian times. The early Chattian in the Antwerp area - despite later erosion (Fig. 6) - is based on the micropalaeontologically proven presence of an early Chattian relict on top of the Boom Formation by Vandenberghe \& Laga (1986). A= city of Antwerp, CB= Campine Block, M= ON-Mol-1 borehole, RVG=Roer Valley Graben, W= Weelde borehole. The boundary fault of the Roer Valley Graben separates the Campine Block in the west from the Roer Valley Graben in the east.

intervals of the ON-Mol-1 and Weelde boreholes at the presumed location of the Oligocene-Miocene hiatus for palynologic analyses. This article presents the results of dinocyst analysis of the ON-Mol-1 and Weelde boreholes (Fig. 3). These results provide new insights in the timing of the Oligocene/Miocene hiatus and its relation to the sedimentary and palaeoenvironmental conditions in the southern North Sea Basin.

\section{Stratigraphy}

The study area is located in the northern part of the Campine Block, a relatively stable tectonic block in the western flank of the differentially subsiding Roer Valley Rift System and along the southern margin of the Cenozoic North Sea Basin (Fig. 2). During most of the Rupelian, the margin of the southern North Sea Basin was receiving clay-rich sediments. The main body of this stratigraphic unit is composed of clays that belong to the Boom Formation. Benthic foraminiferal analyses show that the lower part of the Boom Formation is characterized by normal marine shelf conditions with temporal open connections towards the ocean realm and water depths around $100 \mathrm{~m}$ (De Man \& Van Simaeys, 2004). The upper part of the Boom Formation and the overlying Eigenbilzen Formation show a gradual shallowing and the realization of a poorly ventilated and more isolated marine environment (Van Simaeys et al., 2004). A late Rupelian sea-level low caused temporal sub-aerial exposure of the marginal marine southern North Sea Basin. A striking feature at the RupelianChattian boundary in the southern North Sea Basin is the major change in palaeotemperature (increase) and palaeobathymetry (decrease; Van Simaeys et al., 2004). The latter author states that the latter change is associated with an important shift in lithology, from the clayey silts of the Eigenbilzen Formation in the Rupelian to the glauconite- and fossil-rich, fine-grained, dark green sands of the Voort Formation in the Chattian. The base of the Chattian sequence of the Voort Formation is characterized by marginal marine to brackish-marine conditions, with water depths not exceeding $20 \mathrm{~m}$, while higher up the Chattian successions, conditions return to a normal marine environment (De Man \& Van Simaeys, 2004). Aquitanian deposits are not found so that the earliest Miocene deposits that cover the Campine Block are of the early Burdigalian age and belong to the Berchem Formation (Louwye, 2005). The Berchem Formation consists of shallow marine very glauconiferous, fossil-rich, fine- to medium-grained dark green to black sands that were deposited from the early Burdigalian to Serravallian (Laga et al., 2001). In the Antwerp type area, the Berchem Formation has a distinct basal gravel bed. During the Tortonian and Messinian, the Berchem Formation became covered from east to west by the shallow marine glauconitic sands of the Diest Formation (Louwye et al., 1999).

\section{Material and methods}

\subsection{Material}

The Oligocene strata in the ON-Mol-1 and Weelde boreholes are entirely cored between depths of $150-331 \mathrm{~m}$ and 228 $470 \mathrm{~m}$ respectively. These cores had yet been sampled and biostratigraphically analysed by Van Simaeys et al. (2004; 2005). For our palynological analyses, we tried to take samples from these boreholes at similar locations to be able to compare our results with those from the latter authors. Since our focus was the Oligocene/Miocene boundary, we only sampled the upper parts of the cored interval of the ON-Mol-1 and Weelde boreholes, between depths of 150-174 m and 229-235 m respectively. For the ON-Mol-1 borehole, the entire glauconitic sandy succession on top of the Eigenbilzen Formation was thereby sampled. After the initial results from our palynologic analyses of the ON-Mol-1 borehole, we focused the sampling of the Weelde borehole around a gravel bed at $232.4 \mathrm{~m}$ depth.

Core samples were taken every one to two metres. The locations of the samples are indicated in Figure 3.

\subsection{Methods}

Organic-walled dinoflagellate cysts (dinocysts) analysis has led to significant improvements in the age assessment of the late Paleogene-Neogene successions in NW Europe and in understanding their palaeoenvironmental setting (e.g. Powell, 1986 and 1992; Head et al., 1989; Brinkhuis et al., 1992; Zevenboom, 1995; de Verteuil \& Norris, 1996; Head, 1998; Dybkjær \& Rasmussen, 2000; Köthe, 2007; Köthe et al., 2008; De Schepper \& Head, 2009; Dybkjær \& Piasecki, 2010; Anthonissen, 2012; Quaijtaal et al., 2014; De Schepper et al., 2015, 2017). The potential of dinoflagellate cyst analyses in (bio)stratigraphic differentiation has also been confirmed for the late Paleogene and Neogene intervals in Belgium and the Netherlands (e.g. Louwye, 2002; Louwye et al., 2004; Munsterman \& Brinkhuis, 2004; Van Simaeys et al., 2004, 2005).

Standard palynological techniques, including HCL and HF digestion, $15 \mu \mathrm{m}$ sieving and no oxidation, were applied. The slides were mounted in glycerin jelly. Dinocyst taxonomy is according to that cited in Williams et al. (2017).

One microscope slide per sample was counted until at least 200 palynomorphs (spores, pollen and dinoflagellate cysts) had been identified, the remainder of the slides was scanned for rare taxa. Miscellaneous fossils (like e.g. Pediastrum, Botryococcus) were also counted, but kept outside the total sum of 200 specimens.

The Miocene dinoflagellate cyst (dinocyst) zonation is based on Munsterman \& Brinkhuis (2004), recalibrated to the Geological Time Scale of Ogg et al. (2016). This zonation is based on consistent dinocyst events (mainly on last occurrence datum) from available peer-reviewed palynological contributions in NW Europe and also includes use of a global compilation calibrated to 

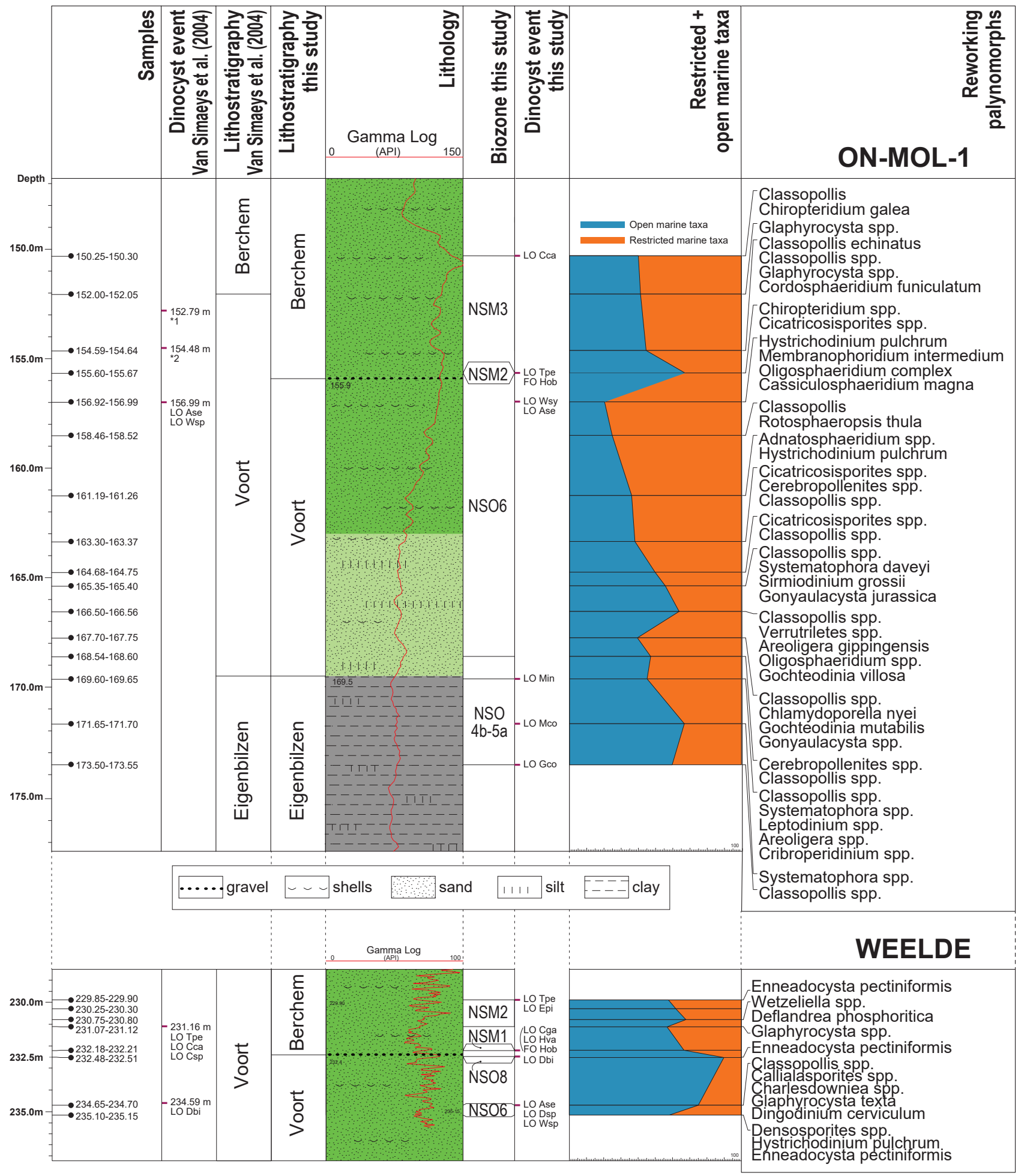

Figure 3. The sample locations, lithology with log-signatures, litho- and biostratigraphy of the Weelde borehole (above; DOV kb8d8e-B161) and ON-Mol-1 borehole (below; DOV ON-Mol-1) according to Van Simaeys et al. (2004) and this study. Abbreviations: FO = First Occurrence; LO = Last Occurrence; Ase = Areoligera semicirculata $; \mathrm{Cga}=$ Chiropteridium galea $; \mathrm{Csp}=$ Chiropteridium spp.; Cca $=$ Cordosphaeridium cantharellum; Dbi $=$ Distatodinium biffi $;$ Dsp = Deflandrea spp.; Epi $=$ Ectosphaeridium picenum $;$ Gco = Gerdiocysta conopeum $;$ Hva = Homotryblium vallum $;$ Hob = Hystrichosphaeropsis obscura; Mco = Membranophoridium connectum; Min = Membranophoridium intermedium; Tpe = Thalassiphora pelagica; $\mathrm{Wsp}=$ Wetzeliella spp., Wsy $=$ Wetzeliella symmetrica.

*1 LO (single specimen and/or inconsistent) of genera Deflandrea and Wetzeliella (in the present study considered as reworking). LO of Distatodinium biffii (Brinkhuis et al., 1992). This taxon differs in characterization from all other species of this genus by the absence of processes in the medial area and a very big size of the central body length: $68-121 \mu \mathrm{m}$ (holotype, $95 \mu \mathrm{m}$ ) and width: $35-63 \mu \mathrm{m}$ (holotype, $52 \mu \mathrm{m}$ ). We measured the central body of the Distatodinium species without processes in the equatorial area of the cyst in our samples and noted that all of them where below the minimum size range boundary in the definition of the taxon. The central bodies are far (ca. 50\%) less in size than that of the holotype. We registered the morphotype as Distatodinium sp. The LOD of this taxon occurs together with Hystrichosphaeropsis obscura in the Miocene.

*2 LO (inconsistent) Areoligera semicirculata (in the present study considered as reworking). 
palaeomagnetic and/or calcareous plankton. The age-assessments have been cross-validated by correlation to recognized sea-level fluctuations. For the Oligocene the zonation scheme of Van Simaeys et al. (2005) is used.

\section{Results}

\subsection{Raised level of reworking}

The palynomorph (sporomorphs and dinoflagellate cysts) recovery is very good in both borehole sections. In general most of the assemblages are well preserved, but not all individual species. Low percentages of species show weathering. Several taxa are evidently not in situ. All core associations include fair numbers of reworking from Paleogene and Mesozoic successions that occasionally may complicate a straightforward dating. Reworking with a provenance in late Jurassic-early Cretaceous successions is very well represented, e.g. by spores Cerebrocysta spp., Cicatricosisporites spp., Corollina (Classopollis) echinatus, Corollina spp., and dinocysts Cassiculosphaerina magna, Chlamydophorella nyei, Gonyaulacysta jurassica, Gonyaulacysta mutabilis, Gonyaulacysta villosa, Hystrichodinium pulchrum, Leptodinium spp., Oligosphaeridium spp., Rotosphaeropsis thula, Sirmiodinium grossi, Systematophora daveyi and Systematophora spp. (Fig. 3). In addition dinocysts with an origin in the Paleogene like e.g. Charlesdowniea spp., Cordosphaeridium funiculatum, Enneadocysta pectiniformis, Glaphyrocysta spp., Glaphyrocysta texta, Membranophoridum intermedium (all Rupelian or older) and Areoligera gippingensis (Paleocene) are recorded. Even very rare occurrences of spores from the Carboniferous, like Densosporites, showed up.

\subsection{Age assessment borehole Weelde (Fig. 4)}

The palynological analyses indicated the following results for the samples at different measured depths along the borehole:

- 229.85-231.12 m: The associations are dated as late Aquitanian-early Burdigalian, Zone M2. The age assessment is based on the last consistent occurrence datums (LOD's) of Ectosphaeridium picenum and Thalassiphora pelagica (Munsterman \& Brinkhuis, 2004; Dybkjær \& Piasecki, 2010). The presence of Cordosphaeridium cantharellum confirms an Early Miocene dating, or older.

- 232.18-232.21 m: The LOD's of Chiropteridium galea and Homotryblium vallum indicate that the early Aquitanian, Zone M1 is reached.

- 232.48-232.51 m: Distatodinium biffii occurs, pointing to a late Chattian age, NSO8 Zone, or older (Williams et al., 2004; Van Simaeys et al., 2005). An older dating is however highly unlikely, because verifying marker taxa for an earlier age are missing. But absence of these species do not entirely rule out this possibility, since the first occurrence datum (FOD) of Distatodinium biffii is in the latest Rupelian.

- 234.65-235.15 m: The assemblages comprise several marine dinocysts associated with an early Chattian age, Zone NSO6, like Areoligera semicirculata, Deflandrea spp., and Wetzeliella spp.

\subsection{Age assessment borehole $\mathrm{ON}$-Mol-01 (Fig. 5)}

The following results of palynological analyses from samples at different measured depths along the borehole are reached:

- 150.25-150.30 m: The LOD of dinocyst Cordosphaeridium cantharellum indicates that the mid-Burdigalian, Zone M3 sensu Munsterman \& Brinkhuis (2004) is reached. An irregular and very rare record of the genus Chiropteridium (Rupelian-Aquitanian range) is considered to be reworked at this depth.

- 155.6-155.67 m: The LOD of Thalassiphora pelagica at $155.6-155.67 \mathrm{~m}$ fits with a late Aquitanian-early Burdigalian age, Zone M2 (Dybkjær \& Piasecki, 2010). An isolated single (not continuous) occurrence of Deflandrea phosphoritica and two indifferent species of Wetzelliella spp. at this depth are interpreted as reworking.

- 156.92-168.60 m: The microflora is interpreted as early Late Oligocene, early Chattian, NSO6 sensu Van Simaeys et al., 2005. The age is based on the LOD's of Wetzeliella symmetrica (156.92-156.99 m), Areoligera semicirculata
(156.92-156.99 m), Deflandrea phosporitica (158.46$158.52 \mathrm{~m})$, Wetzeliella gochtii (158.46-158.52 m), Deflandrea heterophlycta (161.19-161.26 m), Hystrichokolpoma cinctum (166.50-166.56 m) and the FOD of Artemisiocysta cladodichotoma (168.54-168.60 m).

- 169.6 to 173.55 m: The late Early Oligocene, late Rupelian, Zone NSO4b-5a sensu Van Simaeys et al. 2005 is attained. The dating is interpreted on the LOD's of Membranoperidinium intermedium (169.6-169.65 m), Membranoperidinium connectum, Rhombodinium draco $(171.65-171.70 \mathrm{~m})$ and Gerdiocysta conopeum (173.5-173.55 m).

\subsection{Palynofacies of both boreholes $\mathrm{ON}-\mathrm{Mol}-1$ and Weelde (see Figs 2 and 3)}

In both the ON-Mol-1 and Weelde boreholes, marine indicators dominate the in situ palynomorph spectra. The terrestrial component can be substantial, however subordinate to microfossils with a marine origin. Spores comprise $2-17 \%$ of the total sum dinoflagellate cysts and sporomorphs (spores and pollen). Bisaccate pollen (gymnosperms) are present in fluctuating numbers, but in average $32.7 \%$ (ON-Mol-1) - 33.7\% (Weelde) of the total sum dinocysts and sporomorphs. The marine dinocysts are moderately to fairly varied in species richness.

Striking is the occurrence of a "schizosporous" algae that may be very common to abundant in the assemblages (Fig. 3). The algal genus mentioned is Paralecaniella and (in common numbers) associated with coastal (very) restricted marine settings (Louwye \& De Schepper, 2010) or according to King (2016) even brackish conditions. The latter is doubted for the current setting, because typical freshwater (Pediastrum) and brackish (Botryococcus) indicators are missing here. Based on the percentages of this restricted marine Paralecaniella (on the total sum of marine palynomorphs), borehole ON-Mol-1 shows overall (much) higher numbers. The following trends in the values of Paralecaniella were encountered:

- Zone NSO4b-5a shows the lowest values of Paralecaniella (4-5\% in borehole ON-Mol-1) and the highest numbers of the dinocyst genus Spiniferites. The latter has a preferential orientation for open marine conditions.

- The numbers of Paralecaniella increase in the course of the early Chattian, Zone NSO6, in particular at the top of this zone in borehole ON-Mol-1, where percentages up to $65 \%$ (of the total sum of marine palynomorphs) are reached. Here, very restricted marine conditions likely prevail. At the upper part of the NSO6 zone, the increase in the numbers of Paralecaniella coincides with an increase in the gamma-ray values, related to an increased glauconite-content.

- In borehole Weelde, Zone NSO6 shows lower number of Parlecaniella (reaching only 11-12\% Paralecaniella and including relatively substantial numbers of Operculodinium, Achomosphaera and Spiniferites) indicating shallow marine circumstances.

- In the late Chattian Zone NSO8 assemblage of borehole Weelde, the number of Paralecaniella decreases to less than $2 \%$ and in particular genus Spiniferites comprises the highest values (acme). These changes in microflora indicate a return to more open marine conditions.

- In the early Aquitanian Zone NSM1 assemblage of borehole Weelde, the number of Paralecaniella has increased again to $17 \%$, which indicates a return to a shallow marine environment.

- In the subsequent Early Miocene successions shallow to restricted marine circumstances are interpreted, based on the numbers of Paralecaniella (in borehole Weelde, Zone M1: 17\%; Zone M2: 19\%; in borehole ON-Mol-1, Zone M3: 40\%).

\section{Discussion}

\subsection{Comparison with previous studies on the Mol-1 and Weelde boreholes}

Based on our dinocyst analyses, we located the Rupelian/ Chattian boundary at a depth between 168.6 and $169.6 \mathrm{~m}$ in the ON-Mol-1 borehole (Fig. 3). These analyses are in agreement with biostratigraphic and radiometric interpretations of Van Simaeys et al. (2004) and De Man et al. (2010) that identified the Rupelian/Chattian boundary at a depth of $169.5 \mathrm{~m}$. As this 


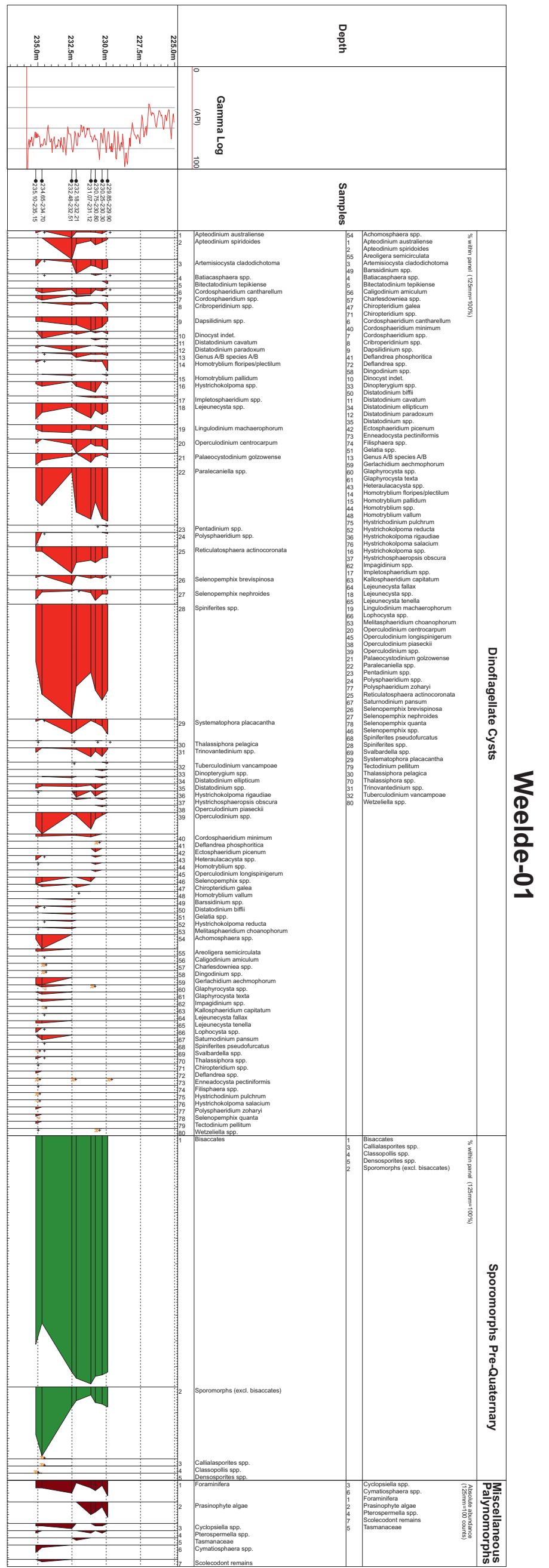

igure 4. Palynological distribution chart of borehole Weelde (DOV kb8d8e-B161).

The chart is also available as supplementary material. 
Figure 5. Palynological distribution chart of borehole ON-Mol-1 (DOV ON-Mol-1).

The chart is also available as supplementary material.

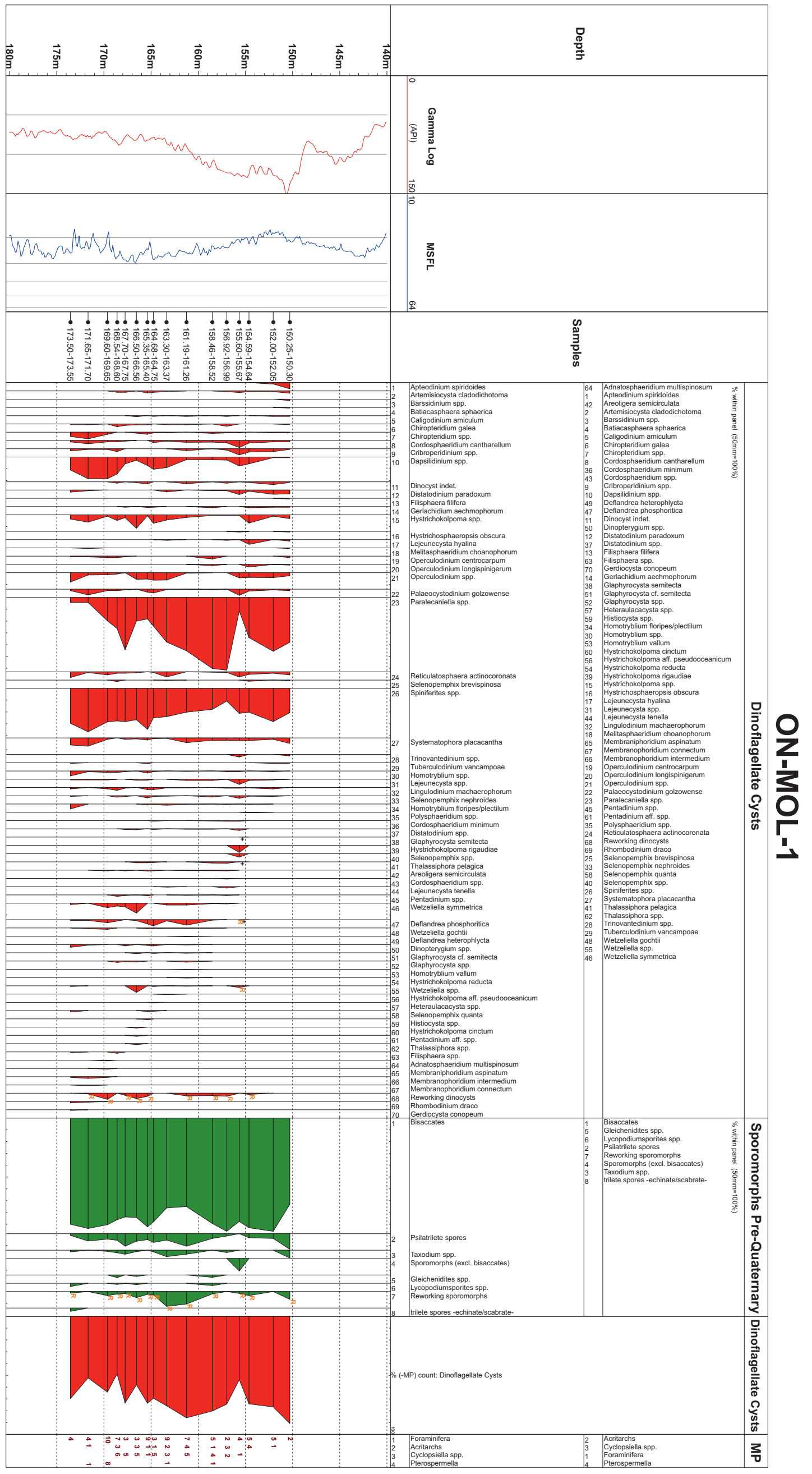


boundary coincides with an abrupt shallowing of the depositional environment or coarsening of the sediment (from silty clay towards silty fine sand in the ON-Mol-1 borehole), it also forms the boundary between the (late Rupelian) Eigenbilzen and (Chattian) Voort Formations (Van Simaeys et al., 2004; Vandenberghe et al., 2004). From the lower boundary of the Voort Formation up to the gravel beds at depths of 155.9 and $232.4 \mathrm{~m}$, respectively in the ON-Mol-1 and Weelde boreholes, our dinocyst analyses continue to be in agreement with the biostratigraphic and radiometric interpretations of Van Simaeys et al. (2004) and De Man et al. (2010) as they point towards a Chattian age. Above the gravel beds, however, the latter authors interpreted a late Oligocene age, while our dinocyst analyses indicate a Miocene age.

Our (re)interpretation of the dinocyst zonation of Van Simaeys et al. (2004) above the gravel beds is based on the following arguments:

- According to this study, the First Occurrence Datum (FOD) of Hystrichosphaeropsis obscura is recorded in the first samples just above the gravel beds in both boreholes. De Verteuil \& Norris (1996) records the FOD of this taxon in the early Miocene (late Aquitanian). Munsterman \& Brinkhuis (2004) confirmed the age of this event in boreholes Groote Heide and Heumensoord (located in the Netherlands).

- Distatodinium biffii is an undisputed marker for the Oligocene (Brinkhuis et al., 1992; de Verteuil \& Norris, 1996; Munsterman \& Brinkhuis, 2004). According to this study and Van Simaeys (2004), the Last Occurrence Datum (LOD) of Distatodinium biffii is reached (in low numbers) in samples below the gravel bed in borehole Weelde. In borehole ON-Mol-1, we did not recorded any Distatodinium biffii contrary to Van Simaeys et al. (2004) who interpreted this taxon in every sample between 152.79-172.56 m. According to our interpretations, the central body lengths of the encountered Distatodinium species are too small (only $50 \%$ of the holotype) to be identified as the current taxon, and were therefore registered as Distatodinium sp. The LOD of Distatodinium sp. is, contrary to Distatodinium biffii, in the Miocene.

- Van Simaeys et al. (2004) identified Chiropteridium sp. above the gravel bed (sample depth $231.16 \mathrm{~m}$ ) in the Weelde borehole, which is also confirmed in our dataset (sample depth 232.18-232.21 m). The LOD of this species indicates that the early Miocene (Aquitanian) is reached (de Verteuil \& Norris, 1996; Munsterman \& Brinkhuis, 2004).

Van Simaeys et al. (2004) show inconsistent occurrences of Wetzeliella, a marker genus for the Oligocene (Van Simaeys et al., 2005), in their two topmost samples above the gravel bed in the ON-Mol-1 borehole, which we interpret as reworking. In general, we noticed several percentages of reworking from late Oligocene and older palynomorphs in the Miocene samples in both the ON-Mol-1 and Weelde boreholes.

Reworking could also explain the inconsistency between the early Miocene biostratigraphic dates of this study and the late Oligocene radiometric dates of glauconite pellets as established by De Man et al. (2010) above the gravel layer in the ONMol-1 borehole. In the overlying glauconitic sands of the Upper Miocene Diest Formation, for example, the difference between dinocyst ages and radiometric ages of reworked glauconite pellets could easily exceed $5 \mathrm{Ma}$ (Vandenberghe et al., 2014).

\subsection{The Oligocene/Miocene boundary (see Figs 3 and 6)}

As the glauconitic fine sands of the Voort Formation become dark green to black in their upper parts in the ON-Mol-1 and Weelde boreholes, their appearance becomes very similar to the typical facies of the overlying Miocene Berchem Formation, which makes it very difficult or even impossible to separate them purely on lithological criteria alone. Within this homogeneous succession of shelly, dark green to black fine glauconitic sands, however, a thin gravel bed was observed in both the ON-Mol-1 and Weelde boreholes at depths of 155.9 and $232.4 \mathrm{~m}$ respectively. Our dinocyst analyses of samples below and above this gravel bed indicate an Oligocene and Miocene age respectively. Since the Voort and Berchem Formation are known to have been deposited during the late Oligocene and early to middle Miocene respectively, the gravel bed also seems to mark their boundary.
Also at other locations in the southern margin of the North Sea Basin, a gravel bed was observed at the base of the Miocene transgression and deposition of the Berchem and Bolderberg Formations. These gravel beds are referred to as "Burcht gravel" in the Antwerp area (Dewalque, 1876) and "Elsloo gravel" in the Limburg area (Halet, 1920). This gravel bed, if encountered, therefore represents a useful criterion to distinguish the Voort and Berchem Formations in the study area. The presence of the regional gravel bed is considered the result of a hiatus after the deposition of the Voort Formation and prior to the deposition of the Berchem Formation. The range of this hiatus is different in the ON-Mol-1 and Weelde boreholes, which might be mainly related to two processes:

- Erosion prior to Miocene deposition due to relative sealevel lowering related to regional tectonic uplift (i.e. Savian phase in Wong et al., 2001; Verbeek et al., 2002; Munsterman \& Brinkhuis, 2004). A relative sea-level fall around the Oligocene-Miocene boundary is supported in this study by the presence of more restricted organic-walled palynomorph assemblages in the early Aquitanian samples (NSM1) compared to the late(st) Chattian samples (NSO8) in the Weelde borehole. The presence of upper(most) Chattian strata in the Weelde borehole indicates that possible tectonic uplift with erosion, if present, could only have been minor at this location. The absence of upper Chattian strata in the ON-Mol-1 borehole indicates that more uplift with erosion could have taken place at this location. However, the absence of upper Chattian strata at this location could also be related to a longer period of exposure after the Oligocene/Miocene sea-level fall compared to the Weelde borehole (which was covered by early Aquitanian strata).

West of the ON-Mol-1 and Weelde boreholes, in the Antwerp area, tectonic uplift related to the Savian phase is evident by complete removal of the Voort Formation and erosion of the upper parts of the Boom Formation underneath the Berchem Formation (Fig. 6).

- The gradual transgression and coverage of the southern margin of the North Sea Basin from north(-west) to south during the early Miocene (Louwye, 2005). This process explains the older age of Miocene sediments in the Weelde borehole (early Aquitanian) compared to the ON-Mol-1 borehole (late Aquitanian to early Burdigalian), as the first is located north of the latter.

The establishment of an early Aquitanian age for the lowermost part of the Berchem Formation in the Weelde borehole is the oldest for the Campine Block (cf. Louwye, 2005). The thin interval (maximum $1.3 \mathrm{~m}$ thickness) of the Aquitanian strata and the northern position of the Weelde borehole compared to other boreholes in the Campine Block, might explain why Aquitanian strata were not identified elsewhere.

\section{Conclusions}

Based on palynologic interpretations, we identified the Oligocene/ Miocene boundary in the cored samples of the ON-Mol-1 and Weelde boreholes in the southern North Sea Basin.

The studied interval contains a substantial number of reworked Paleogene, including irregular upper Oligocene species occurrences (and Mesozoic taxa), which explains why the Miocene strata in the ON-Mol-1 and Weelde boreholes had been dated as late Oligocene by previous studies.

In both boreholes, the Oligocene/Miocene boundary is marked by a thin gravel bed within a continuation of (otherwise undistinguishable) shelly, dark green to black fine glauconitic sands of the Oligocene Voort Formation and early to middle Miocene Berchem Formation.

The gravel beds testify of a hiatus around the Oligocene/ Miocene boundary, which was largest in the ON-Mol-1 borehole as it spans the late Chattian and Aquitanian. The wider range of the hiatus might be the result of the combination of erosion/nondeposition of late Chattian strata and the gradual transgression of the southern North Sea Basin from north (Weelde) to south (ON-Mol-1) after the Oligocene-Miocene relative sea-level fall.

This is the first establishment of an early Aquitanian age for the lowermost part of the Berchem Formation in the Campine Block. 
Figure 6. Schematic cross section of the late Oligocene to late Miocene chrono-, bioand lithostratigraphy from the Weelde borehole across (DOV kb8d8e-B161) the ON-Mol-1 borehole (DOV ON-Mol-1) towards the Antwerp area. The age assessment of the Berchem Formation in the Antwerp area are based on Louwye (2005). In this cross section we presume that the Chattian sediments of the Voort Formation that were deposited in the Antwerp area (see Fig. 2) were eroded prior to the deposition of the Berchem Formation in the same area. The location of this cross section is indicated in Figure 2.

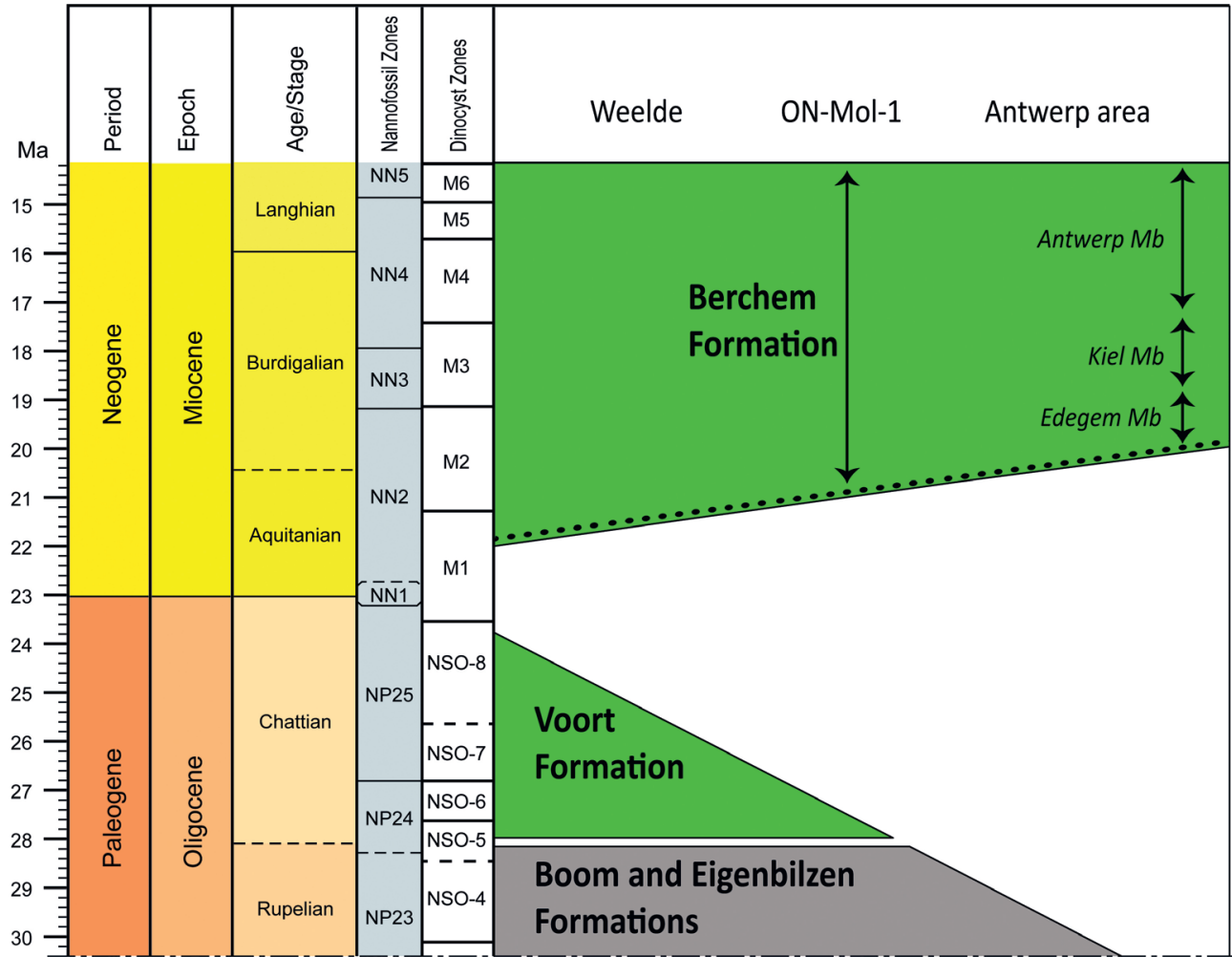

\section{Acknowledgements}

The authors would like thank Noël Vandenberghe, Stefaan van Simaeys, Stephen Louwye, an anonymous reviewer and Etienne Steurbaut for their review, suggestions and discussion, improving our paper substantially. We are grateful to K. Van Baelen for preparing the graphics. Mieke De Craen (ONDRAF/NIRAS) is acknowledged for the availability of the core material and data with reference to the boreholes ON-Mol-1 and Weelde and the permission to publish the results of the current study.

\section{References}

Anthonissen, E., 2012. A new Miocene biostratigraphy for the northeastern North Atlantic: an integrated foraminiferal, bolboformid, dinoflagellate and diatom zonation. Newsletters on Stratigraphy, 45/3, 281-307. https://doi.org/10.1127/0078-0421/2012/0025

Brinkhuis, H, Powell, A.J. \& Zevenboom, D., 1992. High-resolution dinoflagellate cyst stratigraphy of the Oligocene/Miocene transition interval in northwest and central Italy. In Head, M.J. \& Wrenn, J.H. (eds), Neogene and Quaternary Dinoflagellate Cysts and Acritarchs. American Association of Stratigraphic Palynologists Foundation, Dallas, 210-258.

De Man, E. \& Van Simaeys, S., 2004. Late Oligocene Warming Event in the southern North Sea Basin: benthic Foraminifera as paleotemperature proxies. Netherlands Journal of Geosciences, 83/3, 227-239. https://doi.org/10.1017/S0016774600023520

De Man, E., Van Simaeys, S., Vandenberghe, N., Harris, W.B. \& Wampler, J.M., 2010. On the nature and chronostratigraphic position of the Rupelian and Chattian stratotypes in the southern North Sea Basin. Episodes, 33/1, 3-14. https://doi.org/10.18814/epiiugs/2010/ v33i1/002

De Schepper, S. \& Head, M. J., 2009. Pliocene and Pleistocene dinoflagellate cyst and acritarch zonation of DSDP Hole 610A, eastern North Atlantic. Palynology, 33, 179-218. https://doi. org/10.2113/gspalynol.33.1.179

De Schepper, S., Schreck, M., Beck, K.M., Matthiessen, J., Fahl, K. \& Mangerud, G., 2015. Early Pliocene onset of modern Nordic Seas circulation related to ocean gateway changes. Nature Communications, 6, 8659. https://doi.org/10.1038/ncomms9659

De Schepper, S., Beck, K.M. \& Mangerud, G., 2017. Late Neogene dinoflagellate cyst and acritarch biostratigraphy for Ocean Drilling Program Hole 642B, Norwegian Sea. Review of Palaeobotany and Palynology, 236, 12-32. https://doi.org/10.1016/j. revpalbo.2016.08.005 de Verteuil, L. \& Norris, G., 1996. Miocene dinoflagellate stratigraphy and systematics of Maryland and Virginia. Micropaleontology, 42, Supplement, 1-172. https://doi.org/10.2307/1485926

Dewalque, G., 1876. Note sur quelques localités pliocènes de la rive gauche de l'Escaut. Annales de la Société Géologique de Belgique, Mémoires, 3, 12-20.

Dybkjær, K. \& Piasecki, S., 2010. Neogene dinocyst zonation for the eastern North Sea Basin, Denmark. Review of Palaeobotany and Palynology, 161, 1-29. https://doi.org/10.1016/j.revpalbo.2010.02.005

Dybkjær, K. \& Rasmussen, E.S., 2000. Palynological dating of the Oligocene - Miocene successions in the Lille Bælt area, Denmark. Bulletin Geological Society Denmark, 47, 87-103.

Gibbard, Ph.L. \& Lewin, J., 2016. Filling the North Sea Basin: Cenozoic sediment sources and river styles. Andre Dumont medallist lecture 2014. Geologica Belgica, 19/3-4, 201-217. http://dx.doi. org/10.20341/gb.2015.017

Halet, F., 1920. La géologie tertiaire de la Campine anversoise et limbourgeoise. La falaise d'Elsloo et son gravier fossilifère. Bulletin de la Société Belge de Géologie, 30, 84-100.

Head, M.J., 1998. Marine environmental change in the Pliocene and early Pleistocene of eastern England: the dinoflagellate evidence reviewed. In Van Kolfschoten, Th. \& Gibbard, Ph.L. (eds), The dawn of the Quaternary. Mededelingen NITG-TNO, 60, 199-225.

Head, M.J., Norris, G. \& Mudie, P.J., 1989. Palynology and dinocyst stratigraphy of the Upper Miocene and lowermost Pliocene, ODP Leg 105, Site 646, Labrador Sea. Proceedings of the Ocean Drilling Program, Scientific Results, 105, 423-451. https://doi.org/10.2973/ odp.proc.sr.105.135.1989

King, C., edited by Gale, A.S. \& Barry, T.L., 2016. A revised correlation of Tertiary rocks in British Isles and adjacent areas of NW Europe. Geological Society, London, Special Reports, 27, 719 p. https://doi. org/10.1144/SR27

Köthe,A., 2007. Cenozoic biostratigraphy from the German North Sea sector (G-11-1 borehole, dinoflagellate cysts, calcareous nannoplankton). Zeitschrift der Deutschen Gesellschaft für Geowissenschaften, 158, 287-327. https://doi.org/10.1127/1860-1804/2007/0158-0287

Köthe, A., Gaedicke, C. \& Lutz, R., 2008. Erratum: The age of the MidMiocene Unconformity (MMU) in the G-11-1 borehole, German North Sea sector. Zeitschrift der Deutschen Gesellschaft für Geowissenschaften, 159, 687-689. https://doi.org/10.1127/18601804/2008/0159-0687

Laga, P., Louwye, S. \& Geets, S., 2001. Paleogene and Neogene lithostratigraphic units (Belgium). Geologica Belgica, 4, 135-152. https://doi.org/10.20341/gb.2014.050 
Louwye S., 2002. Dinoflagellate cyst biostratigraphy of the Upper Miocene Deurne Sands (Diest Formation) of northern Belgium, southern North Sea Basin. Geological Journal, 37/1, 55-67. https://doi.org/10.1002/gj.900

Louwye, S., 2005. The Early and Middle Miocene transgression at the southern border of the North Sea Basin (northern Belgium). Geological Journal, 40/4, 441-456. https://doi.org/10.1002/gj.1021

Louwye, S. \& De Schepper, S., 2010. The Miocene-Pliocene hiatus in the southern North Sea Basin (northern Belgium) revealed by dinoflagellate cysts. Geological Magazine, 147/5, 760-776. https:// doi.org/10.1017/S0016756810000191

Louwye, S., De Coninck, J. \& Verniers, J., 1999. Dinoflagellate cyst stratigraphy and depositional history of Miocene and Lower Pliocene formations in northern Belgium (southern North Sea Basin). Geologie en Mijnbouw, 78, 31-46.

Louwye S., Head, M.J. \& De Schepper, S., 2004. Dinoflagellate cyst stratigraphy and palaeoecology of the Pliocene in northern Belgium, southern North Sea Basin. Geological Magazine, 141/3, 353-378. https://doi.org/10.1017/S0016756804009136

Munsterman, D.K. \& Brinkhuis, H., 2004. A southern North Sea Miocene dinoflagellate cyst zonation. Netherlands Journal of Geosciences 83/4, 267-285. https://doi.org/10.1017/S0016774600020369

Ogg, J.G., Ogg, G.M. \& Gradstein, F.M., 2016. A Concise Geologic Time Scale. Elsevier, Amsterdam, 234 p. https://doi.org/10.1016/C2009-0-64442-1

Powell, A.J., 1986. Latest Palaeogene and earliest Neogene dinoflagellate cysts from the Lemme section, northwest Italy. AASP Contribution Series, 17, 83-104.

Powell, A.J., 1992. Dinoflagellate cysts of the Tertiary System. In Powell, A.J. (ed.), A Stratigraphic Index of Dinoflagellate Cysts. Springer, Dordrecht, 155-272.

Quaijtaal,W.,Donders, T.H.,Persicoc,D.\&Louwye, S., 2014.Characterising the middle Miocene Mi-events in the Eastern North Atlantic realm: A first high-resolution marine palynological record from the Porcupine Basin. Palaeogeography, Palaeoclimatology, Palaeoecology, 399, 140 159. https://doi.org/10.1016/j.palaeo.2014.02.017

Vandenberghe, N. \& Laga, P., 1986. The septaria of the Boom Clay (Rupelian) in its type area in Belgium. Aardkundige Mededelingen, 3, 229-238.

Vandenberghe, N., Van Simaeys, S., Steurbaut, E., Jagt, J.W.M. \& Felder, P.J., 2004. Stratigraphic architecture of the Upper Cretaceous and Cenozoic along the southern border of the North Sea Basin in Belgium. Netherlands Journal of Geosciences, 83, 155-171. https:// doi.org/10.1017/S0016774600020229

Vandenberghe, N., Harris, W., Wampler, J., Houthuys, R., Louwye, S., Adriaens, R., Vos, K., Lanckacker, T., Matthijs, J., Deckers, J., Verhaegen, J., Laga, P., Westerhoff, W. \& Munsterman, D., 2014. The implications of K-Ar glauconite dating of the Diest Formation on the paleogeography of the Upper Miocene in Belgium. Geologica Belgica, 17, 161-174

Van Simaeys, S., 2004. The Rupelian-Chattian boundary in the North Sea Basin and its calibration to the international time scale. Netherlands Journal of Geosciences, 83, 241-248. https://doi.org/10.1017/ S0016774600023532

Van Simaeys, S., De Man, E., Vandenberghe, N., Brinkhuis, H. \& Steurbaut, E., 2004. Stratigraphic and palaeoenvironmental analysis of the Rupelian-Chattian transition in the type region: evidence from dinoflagellate cysts, foraminifera and calcareous nannofossils. Palaeogeography, Palaeoclimatology, Palaeoecology, 208, 31-58. https://doi.org/10.1016/j.palaeo.2004.02.029

Van Simaeys, S., Munsterman, D.K. \& Brinkhuis, H., 2005. Oligocene dinoflagellate cyst biostratigraphy of the southern North Sea Basin. Review of Palaeobotany and Palynology, 134, 105-128. https://doi. org/10.1016/j.revpalbo.2004.12.003

Verbeek, J.W., De Leeuw, C.S., Parker, N. \& Wong, Th. E., 2002. Characterization and correlation of Tertiary seismostratigraphic units in the Roer Valley Graben. Netherlands Journal of Geosciences, 81, 159-166. https://doi.org/10.1017/S0016774600022393

Wong, Th. E., Parker, N. \& Horst, P., 2001. Tertiary sedimentary development of the Broad Fourteens area, the Netherlands. Netherlands Journal of Geosciences, 80, 85-94. https://doi. org/10.1017/S0016774600022186

Williams, G.L., Brinkhuis, H., Pearce, M.A., Fensome, R.A. \& Weegink, J.W., 2004. Southern ocean and global dinoflagellate cyst events compared: index events for the Late Cretaceous-Neogene. In Exon, N.F., Kennett, J.P. \& Malone, M.J. (eds), Proceedings of the Ocean Drilling Program, Scientific Results, 1-98. https://doi.org/10.2973/odp.proc.sr.189.107.2004
Williams, G.L., Fensome, R.A. \& Macrae, R.A. 2017. The Lentin and Williams index of fossil dinoflagellates. AASP Contribution series, 48, $1097 \mathrm{p}$.

Zevenboom, D., 1995. Dinoflagellate cysts from the Mediterranean Late Oligocene and Miocene. Unpublished Ph.D. Thesis, University of Utrecht, Utrecht, $221 \mathrm{p}$.
Manuscript received 23.11.2018, accepted in revised form 27.04.2020, available online 03.07.2020 